\title{
Comparative study of antibiofilm activity of lime juice and lithium dioxide nanoparticles against Salmonella isolated from local cheese

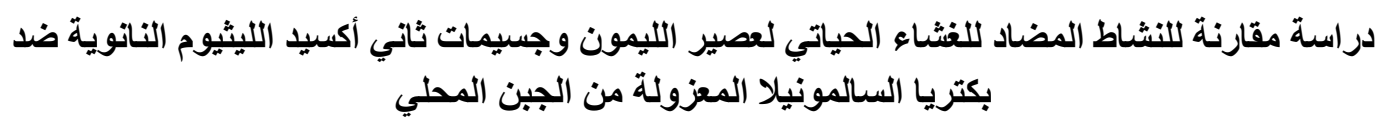

Zainab Zamel Khalaf

College of Science Department of Biology / Baghdad university

$$
\text { قسم علوم الحياة/كلية العلوم/جامعة بغداد }
$$

Corresponding author: zainabalmusawi@yahoo.com

\begin{abstract}
Thirty specimens of fresh white cheeses, presented for sale in different markets at different cities of Iraq were analyzed microbiologically in this study. Isolates of Salmonella, included in the specimens collected from November 2017 to January 2018, were investigated. Capacity for biofilm producing was demonstrated by two method, Tissue culture plate method (TCP) and Congo red agar (CRA).After that the antibiofilm activity of lime extract and $\mathrm{LiO}_{2} \mathrm{NPs}$ was studied as each one of them alone and then the synergistic effect was done by TCP method. The results showed that all Salmonella isolates produce biofilm but in different degrees. The results also displayed that Lime extract and $\mathrm{LiO}_{2} \mathrm{NPs}$ had antibiofilm effect against Salmonella when used alone and when the combination done between each one of these materials. In conclusion, it was observed that the specimens of fresh white cheese included in this study contained microbial contamination at a health-threatening level but we can eliminate this contamination by using lime extract and $\mathrm{LiO}_{2} \mathrm{NPs}$.
\end{abstract}

Key words: Biofilm, LiO2NPs, Lim juice, Congo red, Salmonella, Cheese.

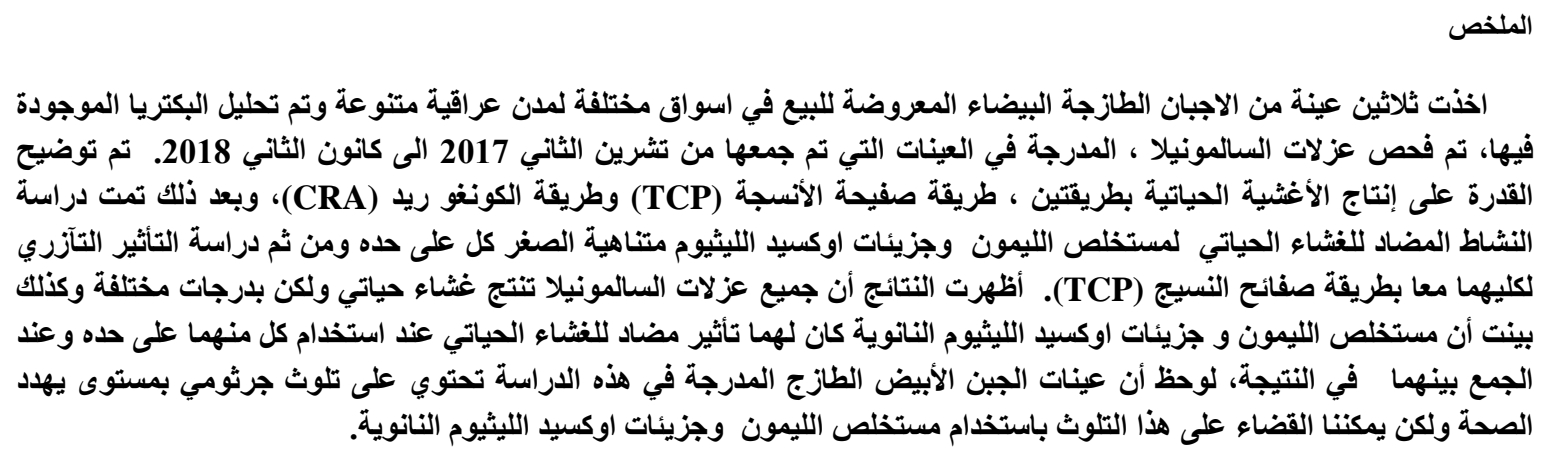

\section{Introduction}

Cheese is an excellent source of protein, fat and minerals such as calcium, iron and phosphorus, vitamins and essential amino acids and therefore is an important food in the diet of both young and old people [1, 2]. It's produced throughout the world in wide-ranging flavors, textures, and forms [3]. The characteristic flavor of cheese is achieved by the addition of starter culture such as lactic acid bacteria which are produced lactic 
acid from lactose, so the cheese was fermented [4]. Cheese is a nutrient that is quite rich in protein and calcium, so it is exhibit a very rapid growth of microorganisms which infect through various sources [5]. Biofilm production in milk tanks and milk development position resulting from the capacity of bacteria to stick and acumulative on stainless steel surfaces. Occasionly for microbial pollution of the processed dairy food caused by biofilms maturation in milk treating places[6]. Salmonella enterica, Escherichia coli O157:H7 and Shigella spp. are among the major food borne pathogens affecting people worldwide [7].

A number of food safety agencies around the world have notified of the dangers of raw-milk cheeses. The U.S. Food and Drug Administration states that soft raw-milk cheeses can cause "severe infectious diseases like salmonellosis [8]. Salmonella that caused this infection characterize as a Gram-negative, facultative anaerobe and rod-shaped bacterium belonging to the family Enterobacteriacea. Some Salmonella serovars frequently foodborne, are capable to become invasive [9]. The alarming incidence of antibiotic resistance in bacteria of medical importance makes there is a constant need for novel and efficient healing agents [10], so we require to apply other antimicrobial agents such as plant extract for example is Citrus aurantium $L$.

Citrus aurantium $L$ has long been inspired in food industry as a part of liqueurs and marmalades, and its extracts have also been using in traditional Chinese medicine to encourage essential energy and exchange, eliminate phlegm, and divide stagnation [11]. Various citrus fruits have been learned for its antimicrobial action comprehensive of both gram positive and gram negative bacteria [12]. Furthermore citrus fruits consumption has been associated with minor risk of numerous chronic diseases [13]. Many researchers study the antimicrobial effect of Citrus fruits alone and as a mixture with other herbs [14, 15] and lime juice has been revealed to have elevated antimicrobial action. Other materials be able to used as antimicrobial agent such as nanoparticles and for many years, it was recognized for its important broad spectrum antimicrobial action against Gram-negative and Gram-positive bacteria, fungi, protozoa and certain viruses [16]. The word "nano" itself belongs to the length scale that is one thousand times smaller than the micro scale. The large surface area of nanoparticles came from its size and make it in contact with the bacterial cells and hence, it will have a higher proportion of interaction than bigger particles, the size of nanoparticles smaller than $10 \mathrm{~nm}$ make them in interact with bacteria and produce electronic effects, which enhance the reactivity of nanoparticles. Currently, Nano therapeutics have been used as antibiofilm through the incorporation of nanoparticles into several substances[17, 18, 19]. From all the information that remembered above this study was aimed to screening bacterial contamination by Salmonella in local cheese, determine biofilm producing isolates by different methods and study the antibiofilm effect of lime extract and $\mathrm{LiO}_{2} \mathrm{NPs}$ against Salmonella isolates.

\section{Materials and Methods}

\section{Isolation and Identification:}

Local fresh- white cheese were collected randomly from local markets in different cities of Iraq during the period from November 2017 to January 2018. Thirty Samples were transferred directly by refrigerater containers to the laboratory and examined immediately without further storage. Five grams of cheese were suspended in $10 \mathrm{ml}$ of buffered peptone water and incubated for $24 \mathrm{~h}$ at $37 \pm^{\circ} \mathrm{C}$. Loop-full from this broth was streaked on to MacConkey agar (Himedia/ India), Salmonella Shigella agar (S.S agar) (Himedia/ India) and Xylose lysine desoxycholate agar (XLD) (Himedia/ India), incubated at $37 \pm^{\circ} \mathrm{C}$ for $24 \mathrm{~h}$. After that, the 
suspected colonies were transferred directly to Triple Sugar iron agar (TSI) and Urea agar base (Himedia/ India) tubes by stabbing the bottom and streaking the slope, and incubated for $24 \mathrm{~h}$ at $37 \mathrm{c}$ (10), for further identification Epi 20 tests were done.

\section{Biofilm assay:}

\section{Tissue culture plate method (TCP)}

The ability of bacterial isolates to form biofilm was achieved by using tissue culture plate method (TCP), all bacterial isolates were cultured in brain heart infusion broth (BHI) containing $1 \%$ glucose in 96-well polystyrene tissue culture plates and incubated at $37 \pm{ }^{\circ} \mathrm{C}$ for $24 \mathrm{hrs}$ under aerobic conditions. After that, the bacterial cells were washed three times with distilled water, and then the adhering cells in each well were fixed with $200 \mu \mathrm{l}$ of absolute methanol for 20 minutes. The plates were emptied and left to dry overnight. The adhering cells were stained of with $0.1 \%$ crystal violet in volume $200 \mu \mathrm{l}$ for $15 \mathrm{~min}$, and excess stain was rinsed off. The plates were washed again with D.W and air-dried overnight. The crystal violate dye fixed to the adherent cells by using $200 \mu \mathrm{l}$ of $96 \%$ ethanol per well, and the plates were read at $490 \mathrm{~nm}$ using a spectrophotometer. The experiment was performed in triplicates, and the absorbance of wells containing sterile BHI broth was used as the control, the result calculate in compare with control as in Table (1).

Table (1): Classification of bacterial adherence by tissue culture plate method (20)

\begin{tabular}{lc}
\hline OD values & Biofilm formation \\
\hline$<\mathrm{OD} \mathrm{c}$ & Not producer \\
$\mathrm{OD}<\mathrm{OD} \leq 2 * \mathrm{ODc}$ & Weak \\
$2 * \mathrm{ODc}<\mathrm{ODt} \leq 2 * \mathrm{ODc}$ & Moderate \\
$4 \mathrm{ODc}<\mathrm{OD} \mathrm{t}$ & strong \\
\hline
\end{tabular}

$\mathrm{OD}=$ optical density, $\mathrm{c}=$ control, $\mathrm{t}=$ test

\section{Congo red methods:}

This method was done following the method illustrated by Freeman et al [21], who styled an alternative method of screening biofilm formation by Staphylococcus isolates; which needs the use of especially prepared solid medium that represent mixture from BHI broth $(37 \mathrm{gms} / \mathrm{L})$, sucrose (50 gms/L), agar no.1 (10 gms/L) and Congo red $\operatorname{stain}(0.8 \mathrm{gms} / \mathrm{L})$. Congo red stain was prepared formerly alone as aqueous solution and autoclaved at $121^{\circ} \mathrm{C}$ for 15 minutes, discretely from additional medium constituents and was then added when the medium had cooled to $45^{\circ} \mathrm{C}$. Culture medium plates were cultured with bacterial isolates and incubated for 24 to 48 hours at $37^{\circ} \mathrm{C}$. Positive result was known by dry black colonies, moderately producer makes gray color and weak slime producers usually pink [22].

\section{Preparation of $\mathrm{LiO}_{2} \mathrm{NPs}$ suspension}

The preparation of nanoparticles was done following to [23], one hundred milligrams of $\mathrm{LiO}_{2} \mathrm{NPs}$ was added to $10 \mathrm{ml}$ of sterile D.W.and shaken vigorously. The suspending solution was treated by ultrasound (40 $\mathrm{kHz}$ ) for $30 \mathrm{~min}$, autoclaved at $121^{\circ} \mathrm{C}$ for $20 \mathrm{~min}$ and then cooled down to room temperature.

\section{Preparation of Lime juice:}

The preparation of lime Juice extract was done according to the methods reported by [12]. Lemon fruits were obtained from the market, samples were cut into halves using sterile knife and the liquid was squeeze out from it individually in sterile container. Care was taken to avoid contamination of the lemon juice during 
squeezing; this extract was marked as $100 \%$ concentrated juice extract. Concentration of $50 \%$ was prepared by diluting the $100 \%$ extract with right volume of sterilized distilled water.

\section{Antibiofilm study of lime juice:}

The antibiofilm activity of lime juice was studied by the same steps that followed for detecting biofilm producing isolates as mentioned earlier, but the different concentrations of lime juice were added in volume 100 with the same volume for bacterial suspension in the wells as triplicate for each concentration, incubated at $37 \pm{ }^{\circ} \mathrm{C}$ for $24 \mathrm{hr}$, after that all wells were washed three times with D.W, stained with $0.1 \%$ crystal violet, and read O.D by ELIZA reader at $490 \mathrm{~nm}$.

\section{Detection the antibiofilm activity of $\mathrm{LiO}_{2}$ against bacterial isolates:}

The same procedure mentioned was followed but different concentrations of $\mathrm{LiO}_{2} \mathrm{NPs}$ were added with bacterial suspension in the wells as triplicate for each concentration, incubated for $24 \mathrm{hr}$ at $37 \pm{ }^{\circ} \mathrm{C}$, after that all wells were washed, stained, and read O.D at $490 \mathrm{~nm}$.

\section{Detection the synergetic antibiofilm activity of $\mathrm{LiO} 2$ and Lime juice against bacterial isolates:}

The anti-biofilm activity of $\mathrm{LiO}_{2} \mathrm{NPs}$ in combination with Lime juice was studied by using TCP assay also. Individual wells were filled with $100 \mu \mathrm{l}$ of the bacterial suspension, after that $\mathrm{LiO}_{2} \mathrm{NPs}$ as mixture with lime extract was added ( $50 \mu \mathrm{l}$ from each one of them). The plate was incubated for 24 hours at $37 \pm{ }^{\circ} \mathrm{C}$, and the wells then washed 3times with D.W, stained with crystal violet for 15 minutes. The stain was rinsed off, resolubilized with ethanol and optical density was measured at $490 \mathrm{~nm}$.The control was considered to represent $100 \%$ of biofilm formation isolates and achieved from the first result of biofilm formation.

\section{Results and Discussion: Isolation and identification:}

The results of present study showed the presence of 84 isolates belong to different bacterial species in cheese samples, Data revealed that (19.04\%) of the cheese samples were contaminated with Salmonella enterica serovar typhi. Study by Nazal,[24] in Iraq reported that (5\%) of the cheese samples were infected with Salmonella spp. This may belong to the low quality of raw milk utilized in cheese producing or due to unsanitary conditions during processing and handling of cheese [25]. Three major food borne pathogens affecting people worldwide are S. enterica, E. coli O157:H7 and Shigella spp. [7]. In the United States, analysis of epidemiological data on food borne disease outbreaks indicated that Salmonella is the most common bacterial etiologic agent, accounting for $52 \%$ of outbreaks attributed to bacteria [26].

Study by Arif [27], investigated that salmonella species cause contamination for three samples from total 120 cheese samples. Other Study by Ashraf and Tadashi, [28] reported that the occurrence of S. enterica was $6.6 \%$ in meat products and $2.0 \%$ in dairy products. Pasteurization destroys pathogenic bacteria which frequently may be present in milk, including those causing of tuberculosis (Mycobacterium bovis), listeriosis ( Listeria monocytogenes), campylobacteriosis (Campylobacter), Salmonellosis (Salmonella) and several other foodborne illnesses (e.g., Esherichia coli O157:H7). Since this kind of cheese formed from unpasteurized milk thus, Salmonella contamination was estimated, furthermore the bad aseptic condition through the industrial, handling and distributing of this product in our local markets increase this capacity for contamination [29]. 


\section{Biofilm assay}

The gold-standard method for this study was TCP method, in compare with data from TM and CRA methods [30].The findings of recent study reported that all bacterial isolates has the ability for producing biofilm but in different degrees, Salmonella isolates formed biofilm in the following percentage, 4 isolates gave strong biofilm, 9 isolates produced moderate biofilm, while only two isolates showed weak biofilm(see figure (2)). Salmonella spp. has confirmed the ability to biofilms producing on several surfaces including different kinds of stainless steel (AISI 304 or 316), polyethylene, polystyrene, acrylic, glass, and metal inert gas (MIG) and tungsten inert gas (TIG) melts [31].

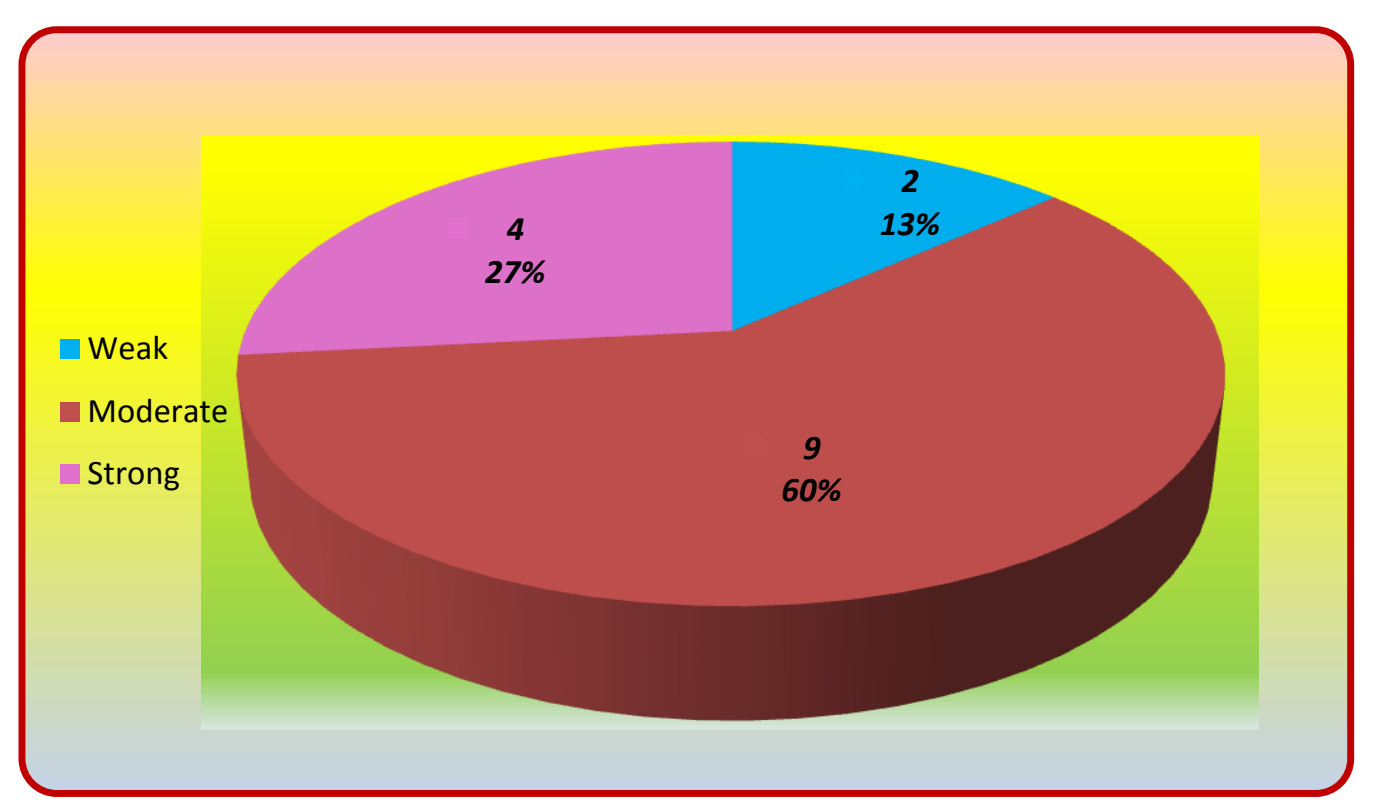

Figure(1): Biofilm producing by S.enterica serovar typhi

Biofilm formation capacity may be an important factor for the persistence of Salmonella on food get in touch with surfaces in the factory surroundings [32]. Biofilms have been commonly associated in chronic infections and environmental persistence of Salmonella enterica, as a result simplifying enhanced colonization of surfaces and expanding the ability of the bacteria to be diffused to new hosts [33]. In conclusion, it was found that there was relationship between the time to clearance of $S$. typhi from typhoid patients after recovery (as gauged by PCR on stool samples) and biofilm production capability. All salmonellae tested in this study are able to form strong biofilms and this result was in agreement with present study [34].

Salmonellosis that caused by Salmonella spp. are represent the most important zoonotic diseases that commonly worldwide, and the most common type of salmonellae infection is enterocolitis. It was found that Salmonella enterica serovars Enteritidis and Typhimurium were the most frequent serotypes secluded from food borne infections, which are capable to of forming biofilm on several surfaces including biotic and abiotic for example: glass, stainless steel, , plastic and living tissues [35,36]. The contact of Salmonella serotypes on biofilm formation capability has not yet been completely explained, and there are few experiments that compare the differences among the serotypes. Descriptions inherent to a specific serotype can effect on its ability for biofilm production [37, 38, 39]. 


\section{Congo red method:}

This is the other procedure by which the biofilm was detected but represent less accurate from microtiter plate method. The present work showed that Salmonella species produce Lipopolysaccharides but in variable values. There are only 4 isolates $(26.66 \%)$ gave positive results that appeared as black crystalline color, 2 isolates(13.33\%) gave gray color that's mean moderate result while all other isolates in percentage $(60 \%)$ gave negative results appeared as orange color. see figure (2). This method was not reliable because of less precision as see by other researchers such as Hassan et al.[30] who explained that CRA method suggested very little association with the other approaches and parameters such as sensitivity, specificity and accuracy were very low, by this method, some isolates were found to be false positive and others were false negative. Knobloch et al [40] did not advised for using CRA procedure for biofilm formation in their study, from 128 isolates of $S$. aureus in this method detected only $3.8 \%$ as biofilm producers as compared to TCP which detected $57.1 \%$ as biofilm producing bacteria. The CRA plate method is not recommended method for detecting biofilm. The same results have been reported by other researchers [41].

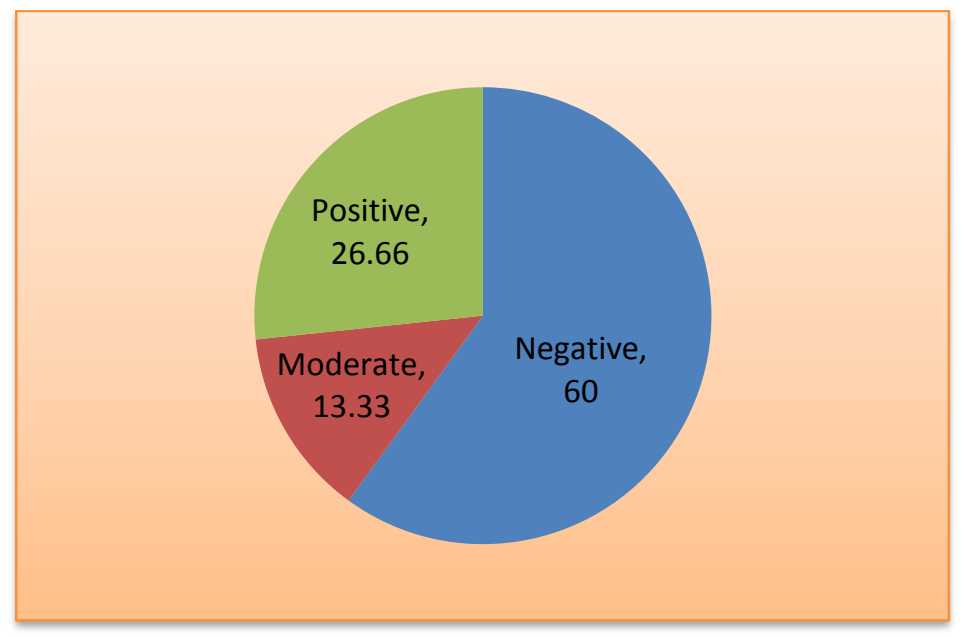

Figure (2): Congo red results for $S$. enterica serovar typhi

Zuberi* and Nadeem [42] reported in their study when compared this method in compare with other results the CRA plate method for detecting biofilm production, reported that only four isolates produced black crystalline morphology, while 111 showed orange colonies

\section{Antibioflm study of lime juice:}

There are few studies about the effect of lime juice against bacterial biofilm and most of them discussed the antibacterial effect of bacteria as planktonic cells. The results of present study revealed that all concentration of lime juice affect on biofilm in Salmonella, the higher antibiofilm effect against Salmonella 26 and 27 was achieved by concentration $12.5 \%$ see figure(3) and (4). Previous studies have shown lemon extract have significant antimicrobial activity against Staphylococcus aureus, Pseudomonas aeruginosa, Escherichia coli and Klebsiella pneumoniae [43]. Other research showed that Lemon juice is not only an astringent but it is also a good antimicrobial agent [44]. Bansode and Chavan,[45] displayed that the fresh crude lemon juice produced the highest antimicrobial activity against Salmonella para typhi B and Shigella sonnei followed by E.coli. 


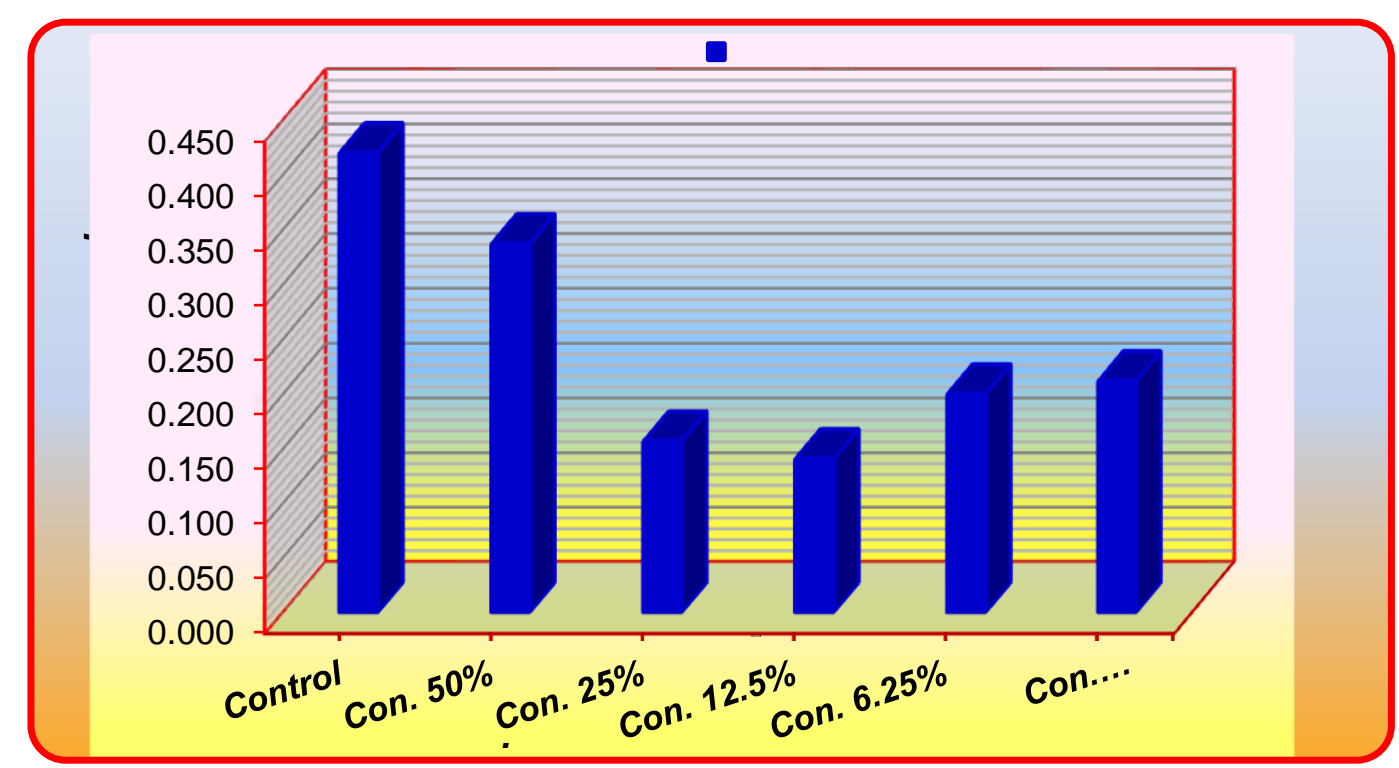

Figure (3): Antibiofilm study of lime juice against Salmonella 26

The figure above showed the effect of different concentration of lime juice against bacterial biofilm , the results demonstrated that lime juice was a good antibiofilm agent as appeared from the percentage of each concentration when compared it with the control ( biofilm of bacteria without lemon).

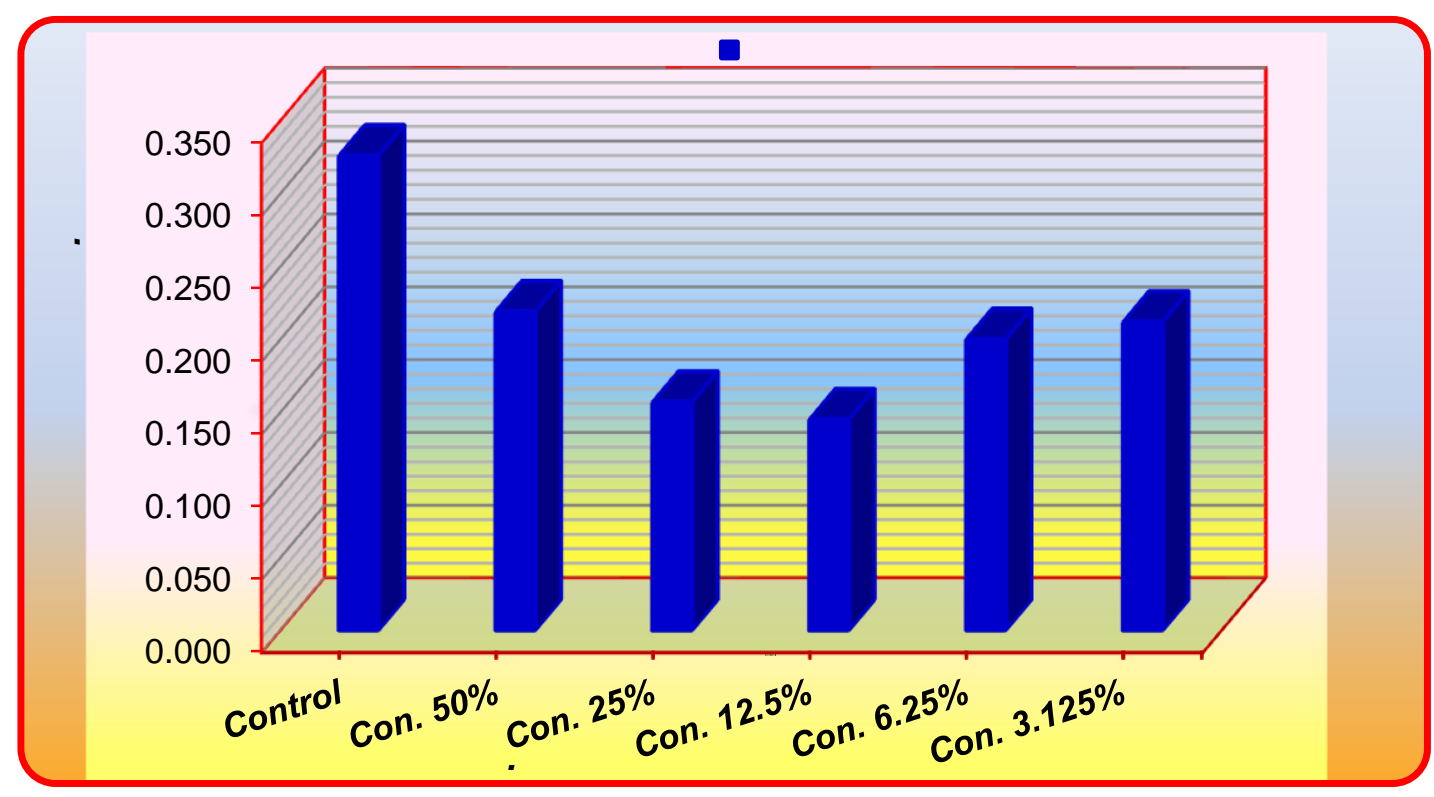

Figure (4): Antibiofilm study of lime juice against Salmonella 27 


\section{Detection the antibiofilm activity of $\mathrm{LiO}_{2} \mathrm{NPs}$ against bacterial isolates:}

The antibiofilm activity of $\mathrm{LiO}_{2}$ was carried by microtiter plate also; LiO2 NPs were prepared in different concentrations and used as antimicrobial materials on biofilm of Salmonella. The current study revealed that all prepared concentration of LiO2NPs had the antibiofilm activity against Salmonella 26 and 27 but higher activity was achieved by $7.8 \mathrm{~J} \mu \mathrm{g} / \mathrm{ml}$ concentration. figure (5) and (6). Studies about the $\mathrm{LiO}_{2}$ activity on biofilm are limited but local study by [46] reported that Nanoparticles $\left(\mathrm{Ag}\right.$ and $\left.\mathrm{Li} \mathrm{O}_{2}\right)$ had effects against adherent cells and mature biofilm that formed by $C$. albicans. The mechanisms causal the antimicrobial activities of NPs are not totally understood and differ from the formations of oxidative and/or free radical formation stressors to DNA damage [47].

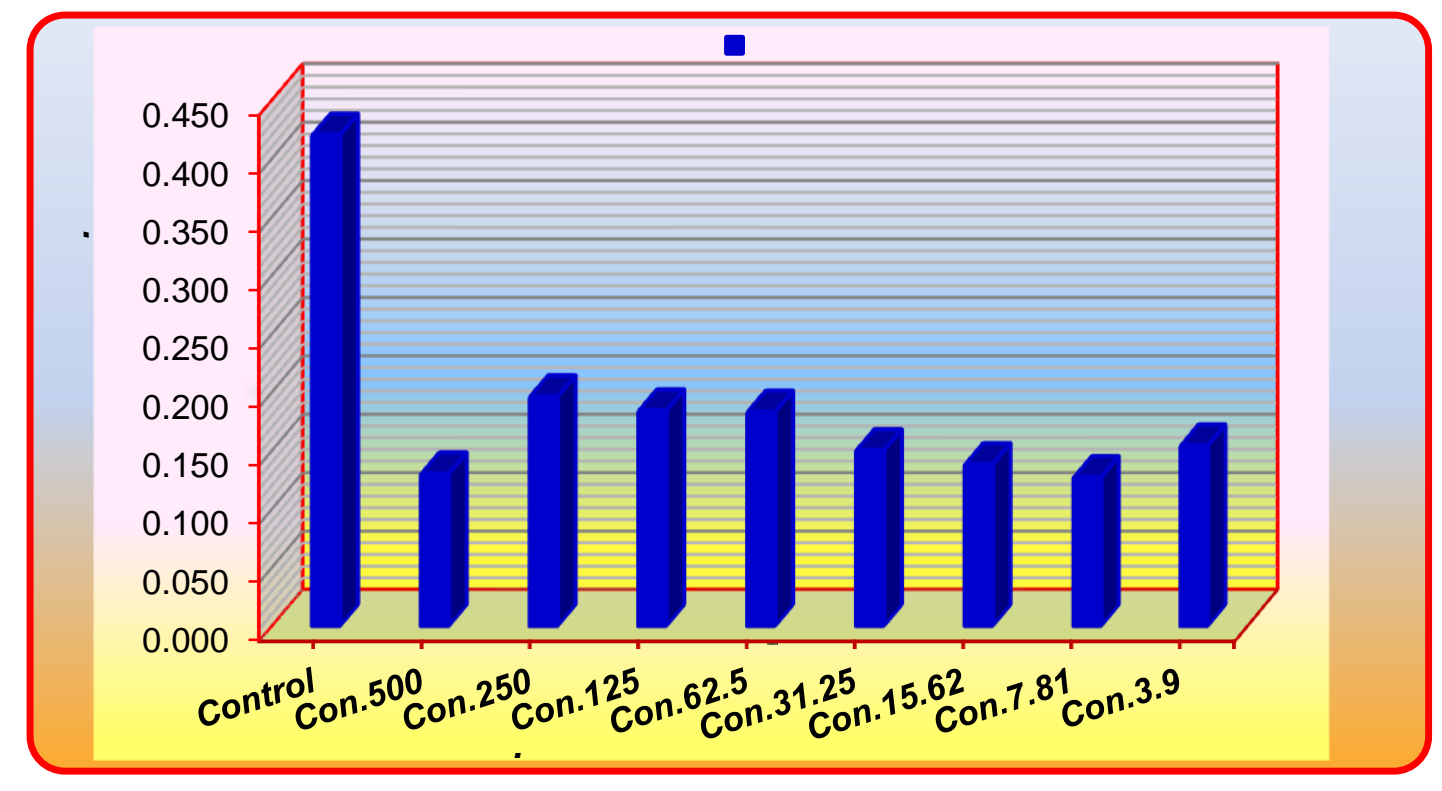

Figure (5): Antibiofilm activity of $\mathrm{LiO}_{2}$ against Salmonella 26

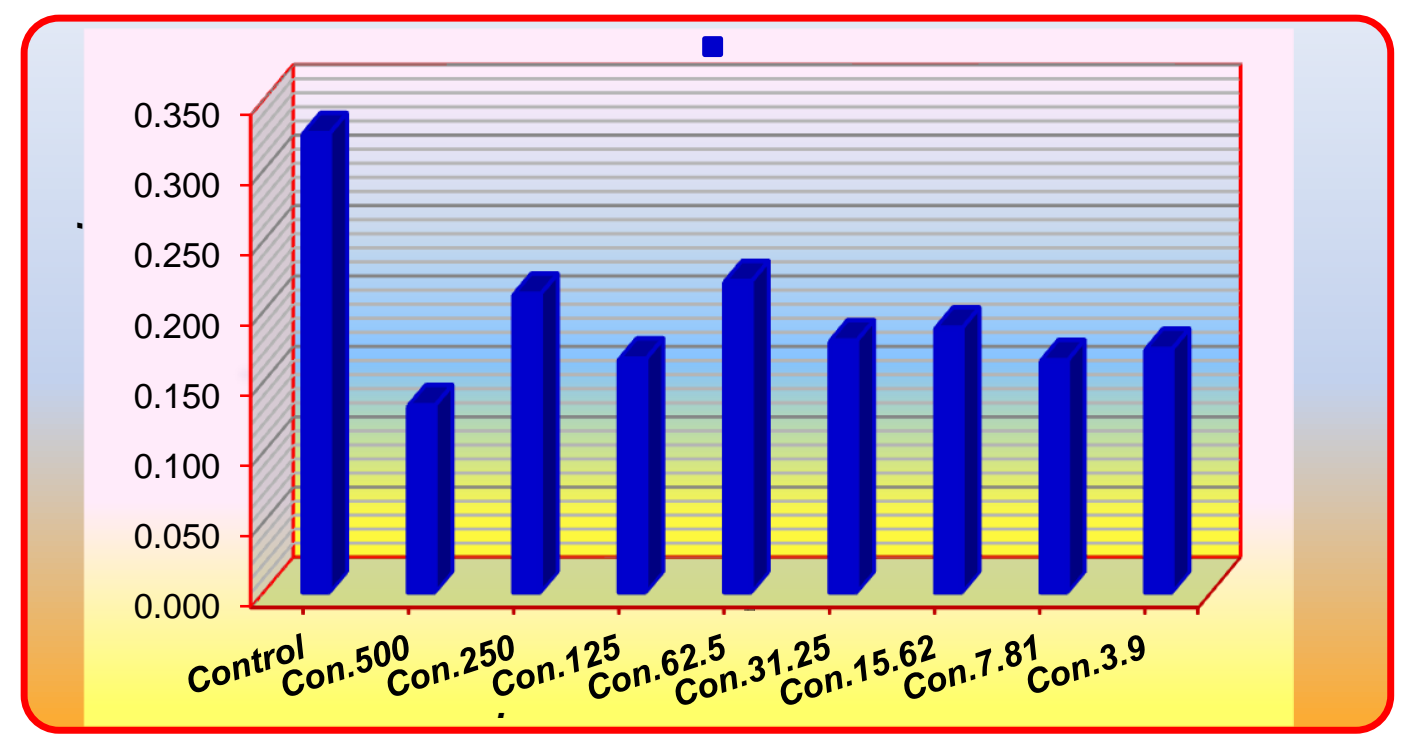

Figure (6):Antibiofilm activity of $\mathrm{LiO}_{2}$ against Salmonella 27 
Detection the synergitic antibiofilm activity of $\mathrm{LiO}_{2} \mathrm{NPs}$ and Lime juice against bacterial isolates:

The synergistic effect of $\mathrm{LiO}_{2}$ NPs and Lime juice was alsostudied, it was found that when the combination between them was done the same antibiofilm activity was achieved but the higher effect against Salmonella 26 observed by the concentration $125 \mu \mathrm{g} / \mathrm{ml}$ from Lime juice and $12.5 \mu \mathrm{g} / \mathrm{ml}$ from $\mathrm{LiO}_{2}$ NPs. The biofilm of Salmonella 27 gave highly effect by concentration $62.5 \mu \mathrm{g} / \mathrm{ml}$ from lime juice and 6.25 $\mu \mathrm{g} / \mathrm{ml}$ from $\mathrm{LiO}_{2}$ NPs. Many studies mentioned that the using of antimicrobial agents combination was more effective than the using of any agents alone like the study by [48] who reported the antifungal effect of silver nanoparticles in combination with chlorhexidine digluconate and nystatin against Candida albicans and C. glabrata biofilms. Local result achieved by [46] showed that the nanoparticles $\left(\mathrm{Ag}\right.$ and $\left.\mathrm{LiO}_{2}\right)$ combination with antifungal(Itraconazole)obtained significant inhibition in mature biofilm as compared with the adherent cells, Significant inhibition happened at most combinations of nanoparticles $\left(\mathrm{Ag}\right.$ and $\left.\mathrm{LiO}_{2}\right)$ with antifungal (Itraconazole) that used. So these fimding were inagreement with the present result on the effect of lime extract and $\mathrm{LiO}_{2} \mathrm{NPs}$ against biofilm.

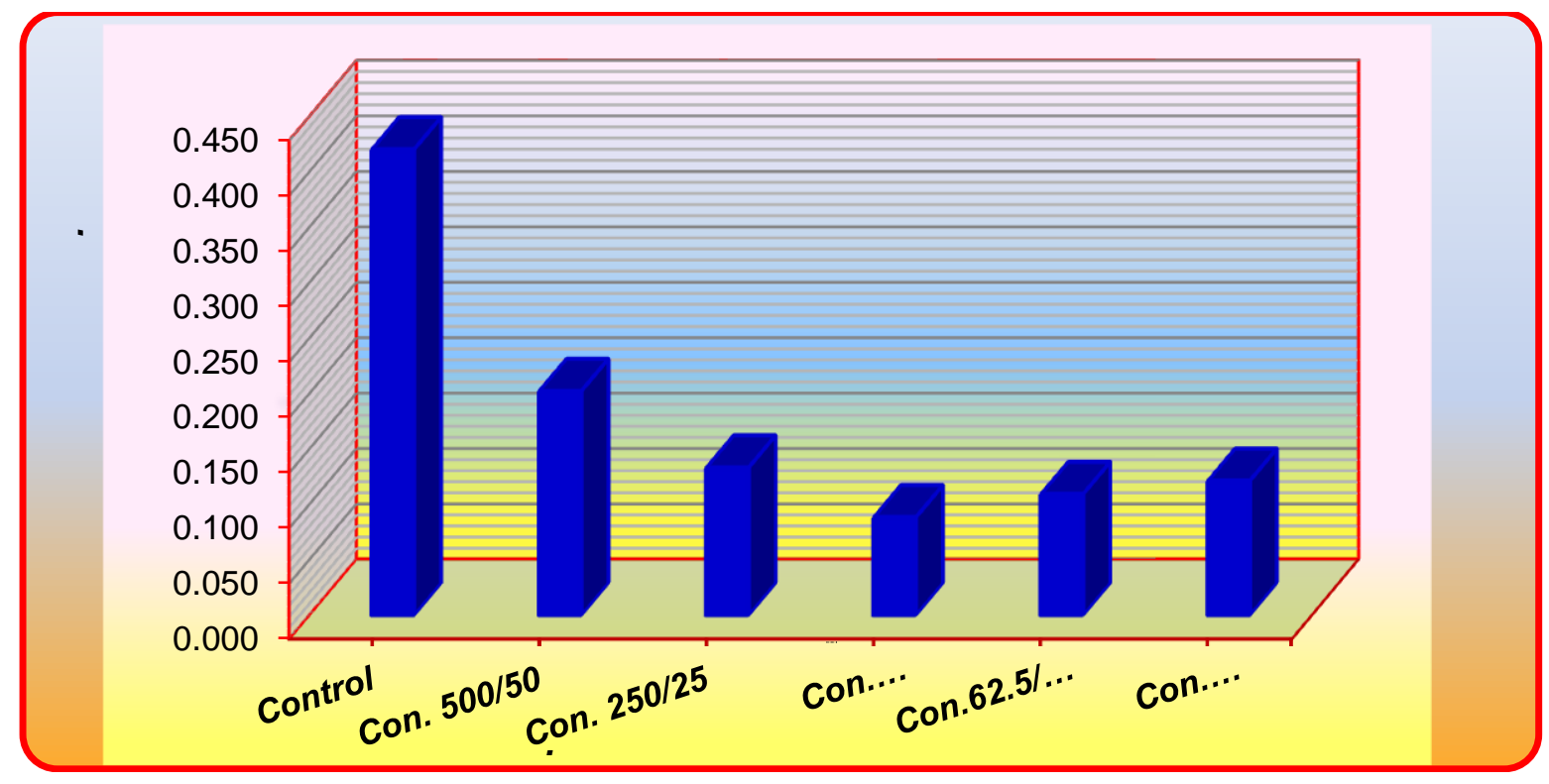

Figure (7): The synergitic antibiofilm activity of $\mathrm{LiO}_{2}$ and Lime juice against Salmonella26 


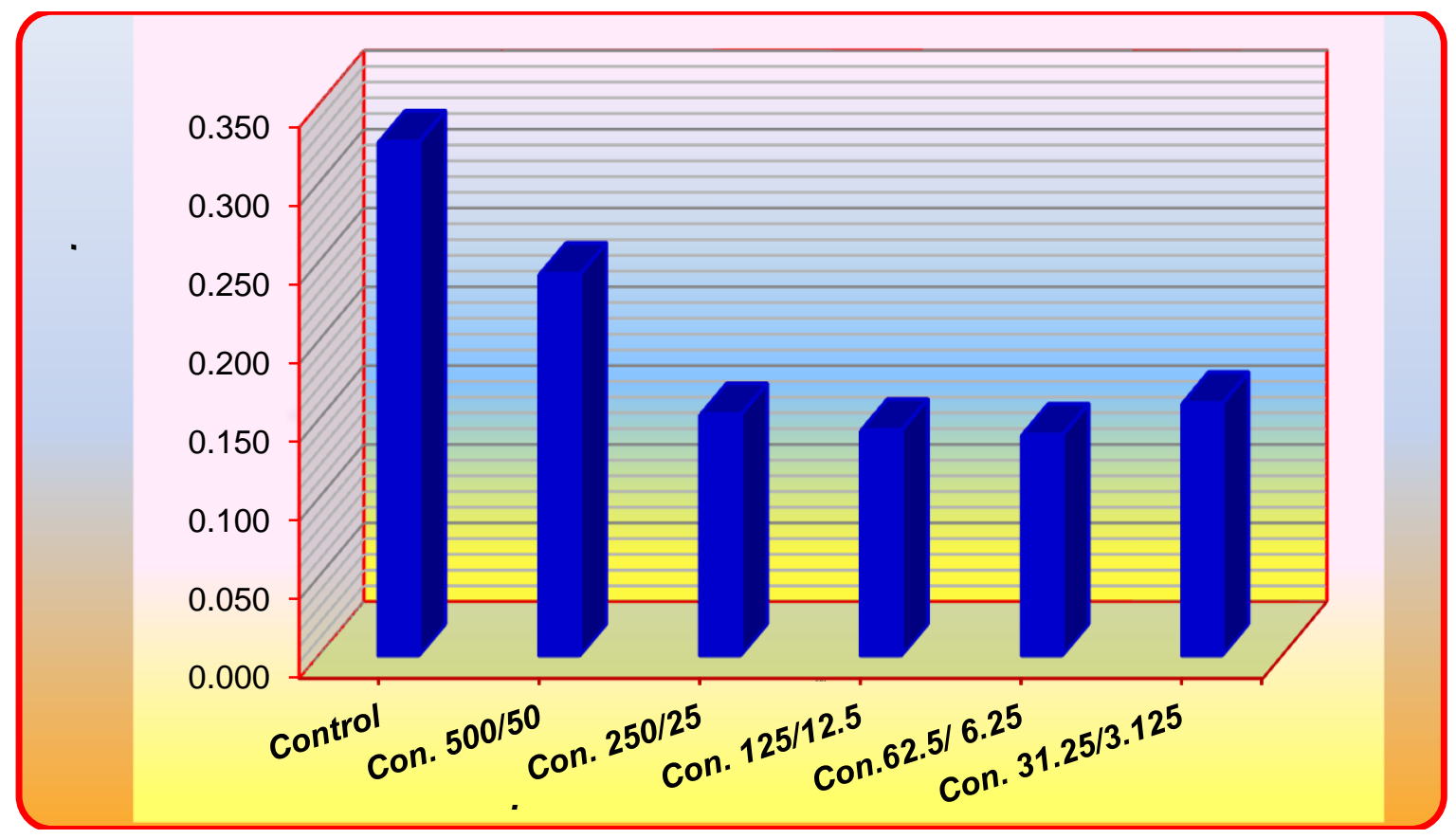

Figure (8): The synergetic antibiofilm activity of $\mathrm{LiO}_{2}$ and Lime juice against Salmonella27

\section{Conclusions:}

The results of current study revealed that lime extract and $\mathrm{LiO}_{2} \mathrm{NPs}$ had the antibiofilm effect against Salmonella isolates when each one of them was used alone or when the combination between them was accur.

\section{Acknowledgments:}

I am very grateful to Prof. Dr.Harith Jabbar AL-Mathkhury and Prof. Dr. May Talib Flayyih, for their valuable advice. This study was supported by laboratory of pathogenic bacteria in Biology Department for College of Science/University of Baghdad.

\section{References:}

1. Tripathi, M.K.; Tyagi, A.K.; Karim, S.A.. (1999).Performance of wiener lambs maintained on mustard and groundnut-meal based diets .Indian J.Anim.Sci.,69(11):991-992.

2. O’Connor, (1993). Traditional cheese making in West Africa. Dairy Technology Paper,3(2):14-18.

3. Verma ,S. K. ; Upadhyay, S. ; Chandra, R. and Pau A.(2013). Preparation of processed cheese spread using tofu, mozzarella and cheddar cheese. International journal of food and nutritional sciences. Vol.2,1923.

4. McGee, H. (2004). Cheese on Food and Cooking. Revised ed. Scribner. PP. 51-63.

5. Evrendilek, G.A., Koca, N., Harper, J.W. and Balasubramaniam, V.M. 2008. High-pressure processing of Turkish white cheese for microbial inactivation. Ournal of Food Protection 71(1):102-108.

6. Sophie Marchand, Jan De Block, Valerie De Jonghe.(2012). An Coorevits, Marc Heyndrickx, and Lieve Herman. Comprehensive Reviews in Food Science and Food Safety. 11:133-147. 
7. CDC, (2010). Preliminary FoodNet data on the incidence of infection with pathogenstransmitted commonly through food-10 states, 2009. Morb. Mortal. Wkly Rep.59, 418-422.

8. Reed, B.; Leslie, B. and Ellen, L. (2011). Division of Agriculture and Natural Resources.Farmstead and Artisan Cheeses:A Guide to Building a Business". University of California .ANR Publications. pp.2-3.ISBN 978-1-60107-692-2.

9. M. Agbaje \& R. H. Begum \& M. A. Oyekunle \& O. E. Ojo \& O. T. Adenubi.2011. Evolution of Salmonella nomenclature: a critical note. Folia Microbiol (2011) 56:497-503.

10. Aibinu, I, Adenipekun, E and Odugbemi, T. (2004). Emergence of Quinolone Resistance amongst Escherichia coli strains isolated from clinical infections in some Lagos State Hospitals in Nigeria. Nig. J. Hlth. Biomed. Sci. 3(2):73-78.

11. M. Ou. (1989). "Chinese-English manual of common-used in traditional Chinese medicine", Hong Kong: Joint Publishing Co., pp.348-349,

12. Owhe-Ureghe, U., Ehwarieme, D. and Eboh, D. (2010). Antibacterial activity of garlic and lime on isolates of extracted carious teeth. African Journal of Biotechnology 9(21): 3163-3166.

13. Nagy, S. 1980. Vitamin C contents of citrus fruit and their products: A review. Journal of Agricultural and Food Chemistry 28(1): 8-18.

14. Rodriguez, A, Sandstrom, A., Ca T., Steinsland, H., Jensen, H. and Aaby, P. (2000). Protection from Cholera by adding limejuice to food-results from community and laboratory studies in Guinea-Bisau, West Africa. Trop. Med. Intern. Hlth., 5(6):418-422.

15. Onyeagba, R. A., Ugbogu, O. C., Okeke, C. U. and Iroakasi, O. (2004). Studies on the antimicrobial effects of garlic (Allium sativum Linn), ginger (Zingiber officinale Roscoe) and Lime (Citrus aurantifolia Linn). Afri.J. Biotechnol., 3(10):552-554.

16. Balazs, D.J; Triandafillu ,K.; Wood, P.;Chevolot, Y.;van Delden, C.; Harms, H.;Hollenstein, C .and Mathieu, H.J.( 2004). Inhibition of bacterial adhesion on PVC endotracheal tubes by RF-oxygen glow discharge, sodium hydroxide and silver nitrate treatments. Bio. 25:2139-2151.

17. Monteiro, D.R., Gorup, L.F., Takamiya, A.S., Ruvollo-Filho, A. C., de Camargo, E.R. and Barbosa, D.B. (2009). The growing importance of materials that prevent microbial adhesion: antimicrobial effect of medical devices containing silver. Int J Antimicrob Agents 34, 103-110.

18. Monteiro, D.R., Gorup, L.F., Takamiya, A.S., de Camargo, E. R., Ruvolo Filho, A.C. and Barbosa, D.B. (2012a). Silver distribution and release from an antimicrobial denture base resin containing silver colloidal nanoparticles. J Prosthodont 21, 7-15.

19. Wady, A.F., Machado, A.L., Zucolotto, V., Zamperini, C.A., Berni, E. and Vergani, C.E. (2012). Evaluation of Candida albicans adhesion and biofilm formation on a denture base acrylic resin containing silver nanoparticles. J Appl Microbiol 112, 1163-1172.

20. Atshan, S.S. M.N. Shamsudin, Z. Sekawi, L.T.T. Lung, R.A. Hamat, A. Karunanidhi, A.A. Mateg, E. Ghaznavi-Rad, H. Ghasemzadeh-Moghaddam, J.S. Chong Seng, J.J Nathan, and C. Pei. (2012). Prevalence of Adhesion and Regulation of Biofilm-Related Genes in Different Clones of Staphylococcus aureus. J. Biomed. Biotech.,3, 10-17. 
21. Freeman, D.J., Falkiner FR, Keane CT. (1989). New method for detecting slime production by coagulase negative staphylococci. J Clin Pathol;42:872-4.

22. Kouidhi,B. T. Zmantar, H. Hentati, and A. Bakhrouf, .(2010). "Cell surface hydrophobicity, biofilmformation, adhesives properties and molecular detection of adhesins genes in Staphylococcus aureus associated to dental caries," Microbial Pathogenesis, vol. 49, no. 1-2, pp. 14-22.

23. Ansari, M.A. M.K. Haris, A.K. Aijaz, S. Asfia,and A. Ameer. (2009). Synthesis and characterization of the antibacterial potential of $\mathrm{ZnO}$ nanoparticles against extended-spectrum b-lactamases-producing E.coli and K. pneumoniaeisolated from a tertiary care hospital of North India. Appl.Microbiol. Biotech.10, 37333736 .

24. Khulood K. Nazal .(2013). Salmonella serotypes isolated and identified from locally white soft cheese. Bas.j.vet.Res. Vol.12,No.2,90-94.

25. Omer, I.A. and Osman, A.O.(2007).Microbiological properties and sensory characteristics of white cheese (Gina bayda) collected in Zalingei Area,West Darfur State.J.of Animal and Vet. Sci., 2:61-65.

26. CDC, .(2009). Surveillance for foodborne disease outbreaks-United States, 2006. Morb. Mortal. Wkly Rep. 58, 609-615.

27. Arif, E. D. (2012).Isolation and identification of Salmonella species from local cheeses in Sulaimani province. Al-Anbar J. Vet. Sci., Vol.: 5 No. (1)

28. Ashraf, M. Ahmed a , Tadashi Shimamoto .(2014).Isolation and molecular characterization of Salmonella enterica, Escherichia coli O157:H7 and Shigella spp. from meat and dairy products in Egypt. International Journal of Food Microbiology 168-169 (2014) 57-62.

29. Mathur, T, Singhal S, Khan S, Upadhyay DJ, Fatma T, et al. (2006). Detection of bLofilm formation among the clinical isolates of staphylococci: An evaluation of three dL gerent screening methods. Indian J Med Microbiol 24: 25-29

30. Hassan, et al., (2011). Evaluation of different detection methods of biofilm formation in the clinical isolates1.Braz J Infect Dis 2011; 15(4):305-311

31. Casarin, L.S., Casarin F.dO., Brandelli A., Novello J., Ferreira S.O. \& Tondo E.C. (2016). Influence of free energy on the attachment of Salmonella Enteritidis and Listeria monocytogenes on stainless steels AISI 304 and AISI 316. LWT Food Sci. Technol. 69:131-1

32. Vestby, L.K., Møretrø T., Langsrud S., Heir E. \& Nesse L.L. (2009). Biofilm forming abilities of Salmonella are correlated with persistence in fish mealand feed factories. BMC Vet. Res. 5:2038.

33. Koopman, J.A., Marshall JM, Bhatiya A, Eguale T, Kwiek JJ, Gunn JS. (2015). Inhibition of Salmonella enterica biofilm formation using small-molecule adenosine mimetics. Antimicrob Agents Chemother 59:76 -84 .

34. Solomon, EB, Niemira BA, Sapers GM, Annous BA. (2005). Biofilm formation, cellulose production, and curli biosynthesis by Salmonella originating from produce, animal, and clinical sources. J Food Prot. 68:906-912.

35. Wong, H. S.Townsend K. M.Fenwick S. G.Trengove R. D. O’Handley R. M (2010).Comparative susceptibility of planktonic and 3-day old Salmonella Typhimurium biofilms to disinfectants.,J. Appl. Microbiol. (108): 2222-2228

36. Rodrigues L.B., Santos L.R., Rizzo N.N., Tagliari V.Z., Oliveira A.P., Trenhago G., Rodegheri S.C., Taglieti R.M., Dickel E.L. \& Nascimento V.P. (2009). Avaliação da hidrofobicidade e da formação de 
biofilmes em poliestireno por Salmonella Heidelberg isoladas de abatedouro avícola. Acta Scient. Vet. 37:225-230

37. Díez-García M., Capita R. \& Alonso-Calleja C. (2012). Influence of serotype on the growth kinetics and the ability to form biofilms of Salmonella isolates from poultry. Food Microbiol. 31:173-180.

38. Schonewille E., Nesse L.L., Hauck R., Windhorst D., Hafez H.M. \& Vestby L.K. (2012). Biofilm building capacity of Salmonella enterica strains from the poultry farm environment. FEMS Immunol. Med. Microbiol. 65:360-365.

39. Castelijn G.A.A., Parabirsing J.A., Zwietering M.H., Moezelaar R. \& Abee T. (2013). Surface behaviour of S. Typhimurium, S. Derby, S. Brandenburg and S. Infantis. Vet. Microbiol. 161:305-314.

40. Knobloch JK, Horsetkotte MA, Rohde H, Mack D. Evaluation of different detection methods of biolfilm formation in Staphylococcus aureus.(2002). Med Microbial Immunol; 191(2):101-6.

41. Taj Y, Essa F, Aziz F, Kazmi SU .(2012). Study on biofilm forming properties of clinical isolates of Staphylococcal aureus. J Infect Dev Ctries 5: 403-409.

42. Zuberi SN, Nadeem SG (2017) Detection of Biofilm Forming Ability of Bacterial Isolates from Contact Lenses and their Accessories. J Bacteriol Parasitol 8: 321.

43. Aqil F, Ahmad I. Antibacterial properties of traditionally used Indian medicinal plants. Methods Find Exp Clin Pharmacol. 2007;29:79-92.

44.Shinkafi, S.A and Ndanusa, H. (2013). Antibacterial activity of citrus limonon acnevulgaris (pimples). IJSIT, 2013, 2(5), 397-409.

45. Bansode,D.S. and Chavan, M.D.(2012). Studies on antimicrobial activity and phytochemical analysis of Citrus fruit juices against selected enteric pathogens. Inter. Res.Pharma. 3(11): 122-126.

46. Al-Salmany, S.T. J. (2016).The Effect of Nanoparticles on the Virulence and Pathogenicity of Candida spp. Ph.D. thesis, PP: 210.

47.Mohankandhasamy Ramasamy and Jintae Le.,(2016). Recent Nanotechnology Approaches for Prevention and Treatment of Biofilm-Associated Infections on Medical Devices. Hindawi Publishing Corporation BioMed Research International Volume 2016, Article ID 1851242, 17

48.Monteiro, D.R.; Silva, S.;Negri, M.;Gorup, L.F.; de Camargo, E.R.,Oliveira, R.;Barbosa, D.B. and Henriques, M.(2013).Antifungal activity of silver nanoparticles in combination with nystatin and chlorhexidine digluconate against Candida albicans and Candida glabrata biofilms. Appl. Microbiol.25:1-9. 